\title{
QUALITY EVALUATION OF SWEETPOTATO-BASED COMPLEMENTARY FOOD
}

*Olatunde, S.J., Oyewole, O.D., Abioye, V.F., Babarinde, G.O and Adetola, R.O

Department of Food Science, Ladoke Akintola University of Technology, Ogbomoso, Oyo State.

*Corresponding Author: sjolatunde@lautech.edu.ng

\section{ABSTRACT}

Complementary Food (CF) was developed using locally available food raw materials (millet, soybean and sweetpotato) to tackle infant malnutrition especially in rural areas. Four different samples of CF were formulated using different ratios of millet flour (MF), sweet potato flour (SPF), soybean flour (SBF); A (55\% MF, 30\% SPF and 15\%SBF), B (50\% MF, 30\% SPF and $20 \% \mathrm{SBF}), \mathrm{C}(45 \% \mathrm{MF}, 30 \% \mathrm{SPF}$ and $25 \% \mathrm{SBF}$ ), and D (40\% MF, 30\% SPF and $30 \% \mathrm{SBF}$ ). Commercial complementary food (Nutribom) was used as control sample. The proximate and functional properties of the formulated CF were determined. The following range of values were obtained for all the complementary samples, moisture (2.98-9.05\%), protein $(5.06-13.19 \%)$, fat $(2.50-8.71 \%)$, fibre $(0.13-2.19 \%)$, ash (1.26-2.31\%) and carbohydrate (55.6$57.6 \%$ ). The protein, fat and fibre contents of the complementary food increased while moisture, ash and carbohydrate contents reduced with an increase in the level of SBF. The water absorption capacity, swelling power, and bulk density of the complimentary food samples ranged between 28.00 and $43.67 \mathrm{ml} / \mathrm{g} ; 2.86$ and5.22 (g/g) and 0.69 and $0.81 \mathrm{~g} / \mathrm{ml}$, respectively. The functional properties of the complementary food increased when compared with the control. The complementary food blends that could be regarded as appropriate formulation based on the exhibited quality attributes evaluated was sample B which contained 50,30 and $20 \%$ of MF, SPF and SBF, respectively. This product can serve as an alternative to commercial weaning food to prevent protein-energy malnutrition, which may help in the growth and development of children among the poor populace.

Keywords: Complementary foods, functional properties, proximate properties and minerals contents 


\section{INTRODUCTION}

Weaning is a period of transition for the infant during which its diet changes in terms of consistency and the child is gradually introduced to semi-solid food (Garcia et al., 2013). Complementary foods are foods and liquids giving to infants other than breast milk or infant formulas for both nutritional and developmental reasons to enable transition from milk feeding to family foods (Abeshu et al., 2016). In Nigeria and many developing countries, commercially available weaning foods are too costly for the average family. This makes the nursing mothers depend often on traditional weaning foods which often are of low nutritive value (Nkeudem et al., 2018).

Sweetpotato (Ipomoea batatas L.) is one of the world's most important, versatile and underexploited food crops (Olatunde et al., 2016). The sweetpotato (SP) tuber grows underground, ranges in flesh colour from cream to yellow, purple or orange, and is high in soluble carbohydrates, minerals and vitamins. It plays an important role in improving household and national food security, health, and livelihoods of poor families in Sub-Saharan Africa (International Potato Center (CIP), 2013). However, the tuber has a short harvest period of about 3-5 months under controlled conditions and shorter under tropical conditions (More et al., 2019) and much work is required to extend the seasonality of the crop. This could be achieved by investigating the methods of utilizing the components of the tuber as food ingredients (Chandrasekara and Kumar, 2016)

Pearl millet (Pennisetum glaucum (L.)) is one of the foremost cereals grown extensively in Nigeria (Tijjani et al., 2018). It contains about $67 \%$ carbohydrate and $12 \%$ protein. The grain is high in ash, iron, and phosphorus and is an important source of the B group of vitamins. Despite the rich nutrient content of the millet, its utilization in Nigeria is limited to the production of household porridge-type breakfast gruel (akamu "dawa") and dough (fura).

Soybean (Glycine max merrill) belongs to the family Leguminosae (Balogun et al., 2012). It contains anti-oxidant and phytonutrients that are associated with various health benefits. Soybean is a rich source of protein because it has an amino acid composition that complements that of cereals. Soybean is exclusively high in protein (about 40\%) and is reported to be one of the most important sources of protein (Shashank et al., 2015; Popovic et al., 2016). About half of the carbohydrate content $(20 \%)$ in soybean is crude fibre which is advantageous in suppressing many degenerative diseases in humans.

Malnutrition is a major health problem in developing countries among the children which contributes to infant mortality, poor physical and intellectual development of an infant, as well as lowered resistance to disease and 
consequently stifles development. Protein-energy malnutrition occurs as a result of the unavailability of low cost, high quality food for the low- income earners. This has led to the formulation and development of nutritious complementary foods from local and readily available raw materials in many developing countries. Cereals and legumes have been reported to be good sources of cheap and high-quality nutrients. Sweet potato is regarded as being high in starch and dietary fibre (Mais and Brennan, 2008). Many researchers have reported the nutrient composition of complementary foods especially in developing countries such as Nigeria. Ijarotimi and Keshinro (2013) evaluated nutritional quality of complementary foods using popcorn, bambara groundnut and African locust beans. Anigo et al. (2010) also attempted to formulate low-cost, nutritive complementary foods using malted maize, millet and sorghum with groundnut and soybean. Little or nothing has been reported on complementary food from combination of sweet potato, pearl millet and soybean despite their abundance locally. Therefore, this research was carried out to develop complementary food from nutritious and locally available food crops such as sweet potato, pearl millet and soybean.

\section{MATERIALS AND METHODS \\ Sample Preparation}

\section{Preparation of Pearl Millet Flour}

The millet grains were cleaned to remove stones, dirts, shafts and other foreign bodies, soaked for 48 hours at ambient temperature $\left(28^{\circ} \mathrm{C}\right)$, then drained. The grains were rinsed with clean water and wet milled. The milled grain was sieved using a clean muslin cloth, decanted and fine slurry was obtained. The slurry was pressed manually in a muslin cloth to remove the water, dried in the cabinet dryer at $65{ }^{\circ} \mathrm{C}$ for 24 hours and milled into fine flour as described by Ojokoh and Onasanya (2017).

\section{Preparation of Soybean Flour}

The method as previously described by Ojokoh and Onasanya (2017) with slight modification was employed. Soybean seeds were cleaned, sorted to remove foreign materials, soaked for 12 hours, and drained. The drained soybean seeds were cooked for 30 minutes, dehulled manually by rubbing between palms, washed and dried in a cabinet dryer at $65{ }^{\circ} \mathrm{C}$ for 24 hours. The dried product was then milled into fine flour. 


\section{Preparation of Sweetpotato Flour}

The method as previously described by Onabanjo and Ighere (2014) with slight modification was employed. The sweetpotato tuber was graded, sorted, washed, peeled, rewashed, sliced into $0.5 \mathrm{~cm}$ thickness, dried in a cabinet drier at $65^{\circ} \mathrm{C}$ for 24 hours and milled.

\section{Formulation of Complementary Food}

Complementary food blends were prepared from flours of sweet potato, millet and soybean using the composite formulation as shown in Table 1.

Table 1: Formulation Table for the Composition of the Sweet Potato Based Complementary Food

\begin{tabular}{llcc}
\hline Sample & Millet $(\%)$ & Sweetpotato $(\%)$ & Soybean $(\%)$ \\
\hline Control & \multicolumn{1}{l}{ Commercial } & complementary food (Nutribom) \\
\hline A & 55 & 30 & 15 \\
B & 50 & 30 & 20 \\
C & 45 & 30 & 25 \\
D & 40 & 30 & 30 \\
\hline
\end{tabular}

\section{Analyses}

\section{Proximate Determination}

The proximate analysis was carried using the method of A.O.A.C (2010).

\section{Functional Properties}

The water absorption capacity was carried out according to the method described by Sosulski et al. (1976). Swelling capacity was determined according to the method given by Robertson et al. (2000). Bulk density was determined using the method described by Onwuka (2005).

\section{The Minerals Analysis}

The calcium $(\mathrm{Ca})$ and magnesium $(\mathrm{Mg})$ were determined by atomic absorption spectrophotometer (AOAC, 2012).

\section{Pasting Properties of Flour and Starch}

The pasting properties of cassava flour and starch were examined using a Rapid Visco-Analyzer (Newport Scientific, Australia) as previously reported by Oyeyinka et al. (2016). 


\section{Statistical Analysis}

The data were subjected to analysis of variance (ANOVA) and means were separated using Duncan's multiple comparison tests through SPSS software (version16.0).

\section{RESULTS AND DISCUSSION \\ Proximate Composition of the Complementary Food}

The moisture contents were significantly different $(p<0.05)$ among the complementary food (CF) samples formulated (Table 1). The moisture content of the control sample (commercial complementary food-Nutribom) was very low compared to the formulated complementary foods. The moisture content of the CF samples was in the ranges of $7.66-9.05 \%$. The value of the moisture contents is close to the values reported by Haque et al. (2013) for CF prepared from sweetpotato and soybean. The protein content of the CF differs significantly $(p<0.05)$ and ranged between 10.82 and $13.19 \%$. The CF formulated with $50 \%$ millet, $30 \%$ SP and $20 \%$ soybean had the highest protein content of $22.74 \%$. This may have been due to the level of soybean in the formulation of the CF. The protein content of the formulated CF samples were about two times that of the control.

The fat content of the sweetpotato based CF ranged between 2.50 and $8.71 \%$, which is about two times higher than the control. The high fat content in the sweetpotato based complementary food could be attributed to the composition of the product. Bonsi et al. (2014) reported a similar result of relatively high fat content in sweetpotato based CF which ranged between 2.85 and $8.92 \%$. The fibre content were significantly different $(p<0.05)$ with sample formulated with 40MF:30SPF:30SBF having the highest fibre content of $2.19 \%$ while sample (50MF:30SPF:20SBF) had the lowest fibre content of $1.13 \%$. The fibre content of the most preferred CF formulated with 50MF:30SPF:20SBF which is $1.13 \%$ is in agreement with the criteria set by Codex Alimentarius Commission (2011) that fibre content of complementary foods should be less than $5 \%$. This is because the presence of high quantity of fibre makes the food bulky and induces flatulence (Codex Alimentarius Commission, 2011) which is an uncomfortable feeling in an infant. The ash content of the CF which is a reflection of the mineral composition differ significantly $(p<0.05)$ and ranged between 1.26 and $2.31 \%$. There was an insignificant difference between the control sample and the sweetpotato based CF. The ash content is relatively high compared to what was reported by Bonsi et al. (2014) for sweetpotato CF. The World Health Organization / Food and Agriculture Organization (WHO/ 
FAO, 2004) 1990 had reported the ash content of a CF should be less than $5 \%$; the most preferred Sample B (50MF:30SPF:20SBF) is in agreement with the standard.

The carbohydrate content of the CF differs significantly $(p<0.05)$ and ranged between 67.59 and $73.80 \%$. Sample formulated with 40MF:30SPF:30SBF has the highest carbohydrate content of $73.80 \%$. However, the value is lower when compared to the control sample which had relatively higher carbohydrate content (86.55\%). Opeifa et al. (2015) reported similar carbohydrate content which ranges between 71.83 and $77.32 \%$ for ogi (paste) produced from fermented maize and horse eye bean. Carbohydrate contributes lots towards energy in CF; its content could be high but must be digestible enough for infants and young children to obtain the energy required or needed.

Table 2: Proximate composition of complimentary foods (\%)

\begin{tabular}{lllllll}
\hline Samples & Moisture & Protein & Fat & Fibre & Ash & CHO \\
\hline Control & $2.98 \pm 0.03^{\mathrm{c}}$ & $5.06 \pm 0.02^{\mathrm{e}}$ & $3.83 \pm 0.13^{\mathrm{d}}$ & $0.13 \pm 0.00^{\mathrm{d}}$ & $1.44 \pm 0.01^{\mathrm{c}}$ & $86.55 \pm 0.09^{\mathrm{a}}$ \\
$\mathrm{A}(55: 30: 15)$ & $8.91 \pm 0.00^{\mathrm{a}}$ & $11.21 \pm 0.09^{\mathrm{c}}$ & $7.77 \pm 0.21^{\mathrm{c}}$ & $1.22 \pm 0.09^{\mathrm{c}}$ & $2.31 \pm 0.07^{\mathrm{a}}$ & $68.56 \pm 0.05^{\mathrm{c}}$ \\
$\mathrm{B}(50: 30: 20)$ & $9.05 \pm 0.21^{\mathrm{a}}$ & $10.82 \pm 0.06^{\mathrm{d}}$ & $8.71 \pm 0.04^{\mathrm{a}}$ & $1.39 \pm 0.02^{\mathrm{b}}$ & $2.05 \pm 0.03^{\mathrm{b}}$ & $67.96 \pm 0.06^{\mathrm{cd}}$ \\
$\mathrm{C}(45: 30: 25)$ & $7.66 \pm 0.36^{\mathrm{b}}$ & $13.19 \pm 0.03^{\mathrm{a}}$ & $8.38 \pm 0.03^{\mathrm{b}}$ & $1.13 \pm 0.03^{\mathrm{c}}$ & $2.02 \pm 0.00^{\mathrm{b}}$ & $67.59 \pm 0.37^{\mathrm{d}}$ \\
$\mathrm{D}(40: 30: 30)$ & $7.67 \pm 0.35^{\mathrm{b}}$ & $12.56 \pm 0.06^{\mathrm{b}}$ & $2.50 \pm 0.04^{\mathrm{e}}$ & $2.19 \pm 0.02^{\mathrm{a}}$ & $1.26 \pm 0.03^{\mathrm{d}}$ & $73.80 \pm 0.44^{\mathrm{b}}$ \\
\hline
\end{tabular}

\section{Functional Properties of the Complementary Food}

The water absorption capacity (WAC) of the complementary food produced ranged between 40 and $43.67 \%$, the highest in sample A (55MF:30SPF:15SBF) and least in sample D (40MF:30SPF:30SBF) (Table 3). The values are higher than the value obtained from the control. The WAC of a food product reflects its ability to absorb moisture. It is defined as the amount of moisture taken up by the flour to achieve a desired consistency or optimal result. The higher values might not be unconnected with high-hydrophilic constituents such as starches and polar amino acid residues which influence their gelation and hydrophilicity capacity (Kaur and Singh, 2005; Ajatta et al., 2016). There are however, no significant differences $(p>0.05)$ among the samples. The values of the bulk density range from $0.75-0.81 \mathrm{~g} / \mathrm{ml}$ and there were no significant differences $(p>$ 0.05 ) among the CF samples. The values are found to be higher than $0.69 \mathrm{~g} / \mathrm{ml}$ obtained for control sample. The presence of fibres in SP might contribute to bulkiness of the CF (Akinjayeju and Ajayi, 2011). Bulk density is an indicator of 
the porosity of food products and influences flour expansion (Kraithong et al., 2018).

The swelling power of the complementary food ranged from 5.10 to $5.22 \%$. Control sample had the lowest swelling power and was significantly different from the rest. Swelling power has been reported to be related to protein and starch contents in foods (Woolfe, 1992). It could further be related to the amylose-amylopectin ratio of the starch where low amylose content leads to a high swelling power (Adebowale et al., 2005).

Table 3: Functional properties of the complementary food

\begin{tabular}{llll}
\hline Samples & WAC $(\%)$ & $\begin{array}{l}\text { Swelling power } \\
(\%)\end{array}$ & Bulk density $(\mathrm{g} / \mathrm{ml})$ \\
\hline Control & $28.00 \pm 0.50^{\mathrm{b}}$ & $2.86 \pm 0.05^{\mathrm{b}}$ & $0.69 \pm 0.00^{\mathrm{a}}$ \\
A $(55: 30: 15)$ & $41.07 \pm 4.29^{\mathrm{a}}$ & $5.10 \pm 0.09^{\mathrm{a}}$ & $0.77 \pm 0.03^{\mathrm{ab}}$ \\
B $(50: 30: 20)$ & $43.33 \pm 3.51^{\mathrm{a}}$ & $5.10 \pm 0.06^{\mathrm{a}}$ & $0.81 \pm 0.04^{\mathrm{ab}}$ \\
C (45:30:25) & $43.67 \pm 4.51^{\mathrm{a}}$ & $5.22 \pm 0.09^{\mathrm{a}}$ & $0.76 \pm 0.02^{\mathrm{ab}}$ \\
D (40:30:30) & $40.00 \pm 5.29^{\mathrm{a}}$ & $5.17 \pm 0.63^{\mathrm{a}}$ & $0.75 \pm 0.04^{\mathrm{ab}}$ \\
\hline
\end{tabular}

Mineral Composition of the Complementary Food

According to Table 4, the calcium content differs significantly $(p<0.05)$ and ranged between $39.30 \mathrm{mg} / 100 \mathrm{~g}$ and $80.47 \mathrm{mg} / 100 \mathrm{~g}$. The most preferred sample (sample B) with $80.47 \mathrm{mg} / 100 \mathrm{~g}$ shows that they are significantly different. The level of calcium in the control sample $(125.97 \mathrm{mg} / 100 \mathrm{~g})$ was higher than that of the other blends probably because most of the commercial complementary foods are fortified and that could be a reason for the relatively high calcium content.

The magnesium content of the complementary food blends (29.87 - 69.56 $\mathrm{mg} / 100 \mathrm{~g})$ was higher than that of the control sample $(29.87 \mathrm{mg} / 100 \mathrm{~g})$. Sample B (50\% millet, $30 \%$ sweetpotato, $20 \%$ soybean) recorded the highest value for magnesium content $(69.56 \mathrm{mg} / 100 \mathrm{~g})$. The level of magnesium in sample B was slightly higher than that of the other blends probably because of the high proportion of soybean in the blend. Soybeans have been reported to be an excellent source of magnesium (Etiosa et al., 2017). 
Table 4: Minerals composition of the complementary food

\begin{tabular}{lll}
\hline Samples & Calcium $(\mathrm{mg} / 100 \mathrm{~g})$ & Magnesium $(\mathrm{mg} / 100 \mathrm{~g})$ \\
\hline Control & $125.97 \pm 0.44^{\mathrm{a}}$ & $29.87 \pm 0.34^{\mathrm{e}}$ \\
A $(55: 30: 10)$ & $39.30 \pm 0.42^{\mathrm{e}}$ & $59.09 \pm 0.03^{\mathrm{d}}$ \\
B $(50: 30: 20)$ & $80.47 \pm 0.46^{\mathrm{b}}$ & $69.56 \pm 0.18^{\mathrm{a}}$ \\
C $(45: 30: 25)$ & $41.80 \pm 0.28^{\mathrm{d}}$ & $62.16 \pm 0.14^{\mathrm{c}}$ \\
D (40:30:30) & $45.27 \pm 0.13^{\mathrm{c}}$ & $65.66 \pm 0.25^{\mathrm{b}}$ \\
\hline
\end{tabular}

\section{Pasting Properties of the Complementary Food}

Pasting temperature is the temperature required to gelatinize starches in a sample. It is an indication of the temperature at which the starch sample will cook (Oyeyinka, 2019). The peak viscosity of the complementary food ranged between 86.13 and $1254.00 \mathrm{RVU}$ as shown in table 5, the ranges are significantly different from the control which has a peak viscosity value of $1180.00 \mathrm{RVU}$. The differences observed in the peak viscosities of the sweet potato based complementary food may be attributed to different rates of water absorption and swelling of starch granules of these complementary food during heating. Ragaee and Abdel-Aal (2006) also observed that peak viscosity usually occurs at the equilibrium between granule swelling, which increases viscosity and granule rupture, and alignment due to mechanical shear. 
Table 5: Pasting properties of complementary food

\begin{tabular}{|c|c|c|c|c|c|c|}
\hline Ratio & $\begin{array}{l}\text { Peak } \\
\text { Viscosity } \\
\text { (RVU) }\end{array}$ & $\begin{array}{l}\text { Trough } \\
\text { (RVU) }\end{array}$ & $\begin{array}{l}\text { Breakdown } \\
\text { (RVU) }\end{array}$ & $\begin{array}{l}\text { Final. Viscosity } \\
(R V U)\end{array}$ & $\begin{array}{l}\text { Set Back } \\
(\mathrm{RVU})\end{array}$ & $\begin{array}{l}\text { Peak time } \\
\text { (Min) }\end{array}$ \\
\hline Control & $\begin{array}{l}1180.00 \pm 0.3^{6} \\
b\end{array}$ & $754.00 \pm 0.1^{\mathrm{cb}}$ & $\begin{array}{l}425.00 \pm 0.14 \\
b^{6}\end{array}$ & $1409.00 \pm 0.13 b^{a}$ & $\begin{array}{l}654.00 \pm 0.14 \\
\mathrm{~b}^{\mathrm{e}}\end{array}$ & $\begin{array}{l}5.00 \pm 0.00 a^{a} \\
b\end{array}$ \\
\hline A & $86.13 \pm 0.20^{\mathrm{e}}$ & $\begin{array}{l}57.04 \pm 0.25 \mathrm{e} \\
\mathrm{a}\end{array}$ & $28.09 \pm 0.22 \mathrm{e}^{6}$ & $105.38 \pm 0.26^{\mathrm{e}}$ & $47.34 \pm 0.21 \mathrm{e}^{\mathrm{d}}$ & $4.74 \pm 0.06 c^{b}$ \\
\hline B & $981.00 \pm 0.1^{d}$ & $\begin{array}{l}668.00 \pm 0.1 \mathrm{c} \\
b\end{array}$ & $314.00 \pm 0.00^{d}$ & $1204.00 \pm 0.13 d^{c}$ & $\begin{array}{l}537.00 \pm 0.11 \\
\mathrm{~b}^{\mathrm{a}}\end{array}$ & $4.77 \pm 0.04 b^{a}$ \\
\hline C & $\begin{array}{l}1254.00 \pm 0.0 \\
\mathrm{a}\end{array}$ & $823.00 \pm 0.1 a^{e}$ & $\begin{array}{l}430.00 \pm 0.15 \\
a^{b}\end{array}$ & $1554.00 \pm 0.14 a^{d}$ & $\begin{array}{l}730.00 \pm 0.16 \\
a^{b}\end{array}$ & $\begin{array}{l}5.06 \pm 0.03 \mathrm{a}^{\mathrm{a}} \\
\mathrm{b}\end{array}$ \\
\hline D & $1048.00 \pm 0 c$ & $68.00 \pm 0.13^{d}$ & $\begin{array}{l}351.00 \pm 0.11 \\
c^{2}\end{array}$ & $1282.00 \pm 0.15 \mathrm{c}^{\mathrm{b}}$ & $585.00 \pm 0.10^{c}$ & $\begin{array}{l}4.86 \pm 0.02 \mathrm{ab} \\
\mathrm{a}\end{array}$ \\
\hline
\end{tabular}

A (55:30:15); B (50:30:20); C (45:30:25); D (40:30:30)

\section{CONCLUSION AND RECOMMENDATION}

The result revealed the potentials of complementary food prepared from millet, soybean and sweetpotato. The processed CF appeared to have a higher/better nutrient profile compared with the commercial products. The protein, fat and fibre contents of the formulated food were significantly higher $(p \leq 0.05)$ than that of control. The higher ash content recorded indicating higher mineral content. The formulation could also be used as food-based approach to solve the problem of protein-energy malnutrition in Nigeria and other Africa countries. Further work is recommended on appropriate packaging for sweetpotato complementary food.

\section{REFERENCES}

Abeshu, M.A., Lelisa, A. and Geleta, B. (2016). Complementary feeding: review of recommendations, feeding practices, and adequacy of homemade complementary food preparations in developing countries-lessons from Ethiopia. Frontiers in Nutrition, 3(41), 1-9.

Adebowale, A.A., Sanni L.O. and Awonorin, S.O. (2005). Effect of texture modifiers on the physicochemical and sensory properties of dried 'fufu'. Food Science and Technology International, 1(5), 373-382.

Ajatta, M.A., Akinola, S.A. and Osundahunsi, O.F. (2016). Proximate, functional and pasting properties of composite flours made from wheat, breadfruit and cassava starch. Applied Tropical Agriculture, 21(3), 158-165. 
Akinjayeju, O. and Ajayi, O.F. (2011). Effects of dehulling on functional and sensory properties of flours from black beans (Phaseolus Vulgaris). Food and Nutrition Sciences, 2, 344-349.

Anigo, K. M., Ameh, D. A., Ibrahim, S. and Danbauchi, S. S. (2010). Nutrient composition of complementary food gruels from malted cereals soybeans and groundnut for use in North- Western Nigeria. African Journal of Food Science, 4(3), 65-72.

Association of Official Analytical Chemists (AOAC) (2010). Official methods of analysis, 18th Edition, Association of Official Analytical Chemists, Washington, D. C., U.S.A.

Association of Official Analaytical Chemists (AOAC) (2012). Official methods of analysis of the Association of Official Analaytical Chemists international (19th editio n). Gathersburg, Maryland, U.S.A.

Balogun, M.A., Karim, O.R., Kolawole, F.L. and Solarin, A.O. (2012). Quality attributes of tapioca meal fortified with defatted soy flour. Agrosearch, 12(1), 61-67.

Bonsi, E.A., Plahar, W.A. and Zabawa, R. (2014). Nutritional enhancement of Ghanaian weaning foods using the orange-fleshed sweet potato. African Journal of Food Agriculture Nutrition Development, 14(5), 92369256.

Chandrasekara, A. and Kumar, T. J. (2016). Roots and tuber crops as functional foods: a review on phytochemical constituents and their potential health benefits. International Journal of Food Science, 16, 115.

Codex Alimentarius Commission (2011). Guidelines on formulated supplementary foods for older infants and young children, Proposed Draft Revision, Codex Alimentarius Commission, Joint FAO/WHO Food Standards Programme, Codex Committee on Nutrition and Foods for Special Dietary Uses, CX/NFSDU 11/33/8.

Etiosa, O.R., Chika, N.B. and Benedicta, A. (2017). Mineral and proximate composition of soya bean. Asian Journal of Physical and Chemical Sciences, 4(3), 1-6.

García, A.L., Raza, S., Parrett, A. and Wright, C. M. (2013). Nutritional content of infant commercial weaning foods in the UK. Archive of Disease of Childhood, 98(10), 793-797.

Haque, M.R., Hosain, M.M., Khatun, H., Alam, R. and Gani, M.O. (2013). Evaluation of nutritional composition and sensory attributes of weaning 
food prepared from sweet potato and soybean. Bangladesh Research Publications Journal, 8(2), 127-133.

ljarotimi, S. O. and Keshinro, O. O. (2013). Determination of nutrient composition and protein quality of potential complementary foods formulated from the combination of fermented popcorn, African Locust and Bambara Groundnut Seed Flour. Polish Journal of Food and Nutritional Sciences, 63(3), 155-166.

Kaur, M., and Singh, N. (2005). Studies on functional, thermal and pasting properties of flours from different chickpea (Cicer arietinum L.) cultivars. Food Chemistry, 91(3), 403-411.

Kraithong, S., Lee, S., and Rawdkuen, S. (2018). Physicochemical and functional properties of Thai organic rice flour. Journal of Cereal Science, 79, 259-266.

Mais, A. and Brennan, C.S. (2008). Characterization of flour, starch and fibre obtained from sweet potato (kumara) tubers, and their utilisation in biscuit production. International Journal of Food Science and Technology, 43(2), 373-379.

More, S.J., Ravi, V. and Raju, S (2019). Post-harvest physiology of tropical tuber crops In: Postharvest Physiological Disorders in Fruits and Vegetables S.T. De Freitas, and S. Pareek, (Eds), Boca Raton: CRC press.

Nkeudem, A. G., Ngole, S.I.U., Judith, A., Ning, T.R., Metuge, S. and Giscard, K.K. (2018). Nutritional Evaluation of commonly used local weaning food processed and sold in the mount Cameroon region. International Journal of Food Science and Nutrition Engineering, 8(6), 131-141.

Ojokoh, A. O. and Onasanya, T.T. (2017). Effect of fermentation and extrusion on the nutrient and anti-nutrient composition of soybeans (Glycine max, L) and Acha (Digitaria exilis Stapf). Microbiology Research Journal International, 21(1), 1-21.

Olatunde, G.O., Henshaw, F.O., Idowu, M. A. and Tomlins, K. (2016). Quality attributes of sweet potato flour as influenced by variety, pretreatment and drying method. Food Science and Nutrition, 4(4), 623-635.

Onabanjo, O.O. and Ighere, D. A. (2014). Nutritional, functional and sensory properties of biscuit produced from wheat-sweet potato composite" Journal of Food Technology Research, 1(2), 111-121.

Onwuka, G.I. (2005). Functional properties in: Food analysis and instrumentation. Naphtali Prints, Lagos. Pp 134-135. 
Opeifa, A.O. Olatidoye, O.P. Adesala, S.O. and Fayomi, M.J. (2015). Production and Quality Evaluation of Ogi Produced from Fermented Maize and Horse Eye Bean (Mucuna urens) Pakistan Journal of Nutrition, 14 (7), 417-425.

Oyeyinka, S. A., Adeloye, A. A., Smith, S. A., Adesina, B. O. and Akinwande, F. F. (2019). Physicochemical properties of flour and starch from two cassava varieties. Agrosearch, 19(1), 28-45.

Oyeyinka, S. A., Singh, S., and Amonsou, E. O. (2016). Physicochemical properties of starches extracted from bambara groundnut landraces. Starch-Stärke, 69(3-4), 1-8.

Popovic, V., Tatic, M., Sikora, V., Ikanovic, J., Drazic, G., Djukic, V., Mihailovic, B., Filipovic, V., Dozet, G. and Jovanovic, L. (2016). Variability of yield and chemical composition in soybean genotypes grown under different agro-ecological conditions of Serbia. Romanian Agricultural Research, 33, 29-39.

Ragaee, S. and Abdel-Aal, E-S.M. (2006). Pasting properties of starch and protein in selected cereals and quality of their products. Food Chemistry, 95, 9-18.

Robertson, G.L., Monredon, F.D., Dysseler, P., Guillon, F., Amado, R, and Thibault, J.F. (2000). Hydration properties of dietary fibre and resistant starch: a European collaborative study. LWT Food Science and Technology, 33, 72-79.

Shashank A., Tidke, D., Ramakrishna, S., Kiran, G. Kosturkova and. Ravishankar, G.A. (2015). Nutraceutical Potential of Soybean: Review. Asian Journal of Clinical Nutrition, 7, 22-32.

Sosulski, F.W., Garrat, M.O. and Slinkard, A.E. (1976). Functional properties of the legume flours. Food Science and Technology Journal, 9, 66-69.

Tijjani, H., Umar, B.F., Abubakar, B.Z. and Aliyu, U. (2018). Socio-economic determinants of adoption of improved millet production practices by farmers in Borno State, Nigeria. Agrosearch, 18(2), 86-100.

WHO/ FAO (2004). Human vitamin and mineral requirements. Report of a joint FAO/WHO consultation, Bangkok, Thailand. Rome: Food and Agriculture Organization of the United Nations (FAO) and World Health Organization (WHO).

Woolfe, J.A. (1992). Sweet potato: An untapped food resource. Cambridge University Press. 